

\title{
In situ reduction and evaluation of anode supported single chamber solid oxide fuel cells
}

Damien Rembelski, Mathilde Rieu, Lionel Combemale, Jean-Paul Viricelle

\section{To cite this version:}

Damien Rembelski, Mathilde Rieu, Lionel Combemale, Jean-Paul Viricelle. In situ reduction and evaluation of anode supported single chamber solid oxide fuel cells. Journal of Power Sources, 2013, 242 (15), pp.811-816. 10.1016/j.jpowsour.2013.05.118 . hal-00840106

\section{HAL Id: hal-00840106 https://hal.science/hal-00840106}

Submitted on 1 Jul 2013

HAL is a multi-disciplinary open access archive for the deposit and dissemination of scientific research documents, whether they are published or not. The documents may come from teaching and research institutions in France or abroad, or from public or private research centers.
L'archive ouverte pluridisciplinaire HAL, est destinée au dépôt et à la diffusion de documents scientifiques de niveau recherche, publiés ou non, émanant des établissements d'enseignement et de recherche français ou étrangers, des laboratoires publics ou privés. 


\section{In situ reduction and evaluation of anode supported single chamber}

\section{solid oxide fuel cells}

D. Rembelski ${ }^{\text {a }}$, M. Rieu ${ }^{\text {a, }}$, L. Combemale ${ }^{\text {b }}$, J.P. Viricelle ${ }^{\text {a }}$

${ }^{a}$ Ecole Nationale Supérieure des Mines, SPIN-EMSE, CNRS:UMR5307, LGF,

F-42023 Saint-Etienne / France

${ }^{\mathrm{b}}$ Laboratoire Interdisciplinaire Carnot de Bourgogne

9 avenue Alain Savary

FR-21078 Dijon / France

* Corresponding author: M. Rieu

Tel.: +334774202 82; Fax: +33477499694

E-mail address: rieu@emse.fr 


\begin{abstract}
Single chamber anode-supported fuel cells are investigated under several methane-oxygennitrogen atmospheres at intermediate temperatures $\left(500^{\circ} \mathrm{C}-700^{\circ} \mathrm{C}\right) . \mathrm{Ce}_{0.9} \mathrm{Gd}_{0.1} \mathrm{O}_{1.95}(\mathrm{CGO})$ is chosen as electrolyte and deposited by screen-printing onto NiO-CGO anode pellets. A cathode composed of $70 \mathrm{wt} \% \mathrm{La}_{0.6} \mathrm{Sr}_{0.4} \mathrm{Co}_{0.2} \mathrm{Fe}_{0.8} \mathrm{O}_{3-\delta}$ (LSCF) and $30 \mathrm{wt} \%$ of CGO is screen-printed onto the electrolyte. Thermogravimetric analyses of anode reduction are performed at $700^{\circ} \mathrm{C}$. Carbon deposition is observed under diluted methane but a successful reduction is obtained after an initialization under diluted methane followed by a final treatment under methane-to-oxygen ratio (Rmix) of 2. Anode-supported fuel cells are investigated regarding the working temperature and Rmix. Two types of cells are prepared with modifications of the electrolyte microstructure. For both cells tested, the Open Circuit Voltage (OCV), the power density and the fuel utilization increase when Rmix and temperature decrease. The electrolytes of both cells have a porous microstructure and the electrolyte of the second cell, with the highest thickness, brings better performances. At $600^{\circ} \mathrm{C}$ for $\mathrm{Rmix}=0.6$, the maximum power density is improved from 60 for the first cell to $160 \mathrm{~mW} \mathrm{~cm}^{-2}$ for the second cell. Comparing the fuel utilization, it increases from $3 \%$ for the first cell to $6 \%$ for the second one for the same testing conditions.
\end{abstract}




\section{Introduction}

Single Chamber Solid Oxide Fuel Cells (SC-SOFC) is an innovative kind of SOFC which have mostly been developed during the past decade [1-4]. Contrary to conventional SOFCs, SCSOFCs work in an atmosphere where the fuel and the oxygen are mixed; this configuration allows a more flexible geometry without any needed sealing. Hydrocarbons are generally used instead of hydrogen because of a smaller flammability area. The working principle is based on the difference of catalytic activity between cathode and anode: the anode must be selective to the partial oxidation of hydrocarbons while the cathode must be selective to the reduction of oxygen. Methane which is the most common fuel used in SC-SOFC is chosen for this study. Therefore, the main reactions which can occur are reactions I, II III and IV at the anode side and reaction V at the cathode side. Volume methane to oxygen ratio is noted Rmix in this paper.

$\begin{array}{lll}1 / 2 \mathrm{CH}_{4}+\mathrm{O}_{2} \rightarrow \mathrm{H}_{2} \mathrm{O}+1 / 2 \mathrm{CO}_{2} & \text { total combustion of } \mathrm{CH}_{4}(\mathrm{Rmix}=0.5) & \text { (reaction } \mathrm{I}) \\ 2 \mathrm{CH}_{4}+\mathrm{O}_{2} \rightarrow 4 \mathrm{H}_{2}+2 \mathrm{CO} & \text { partial combustion of } \mathrm{CH}_{4}(\mathrm{Rmix}=2) & \text { (reaction II) } \\ \mathrm{H}_{2}+\mathrm{O}^{2-} \rightarrow \mathrm{H}_{2} \mathrm{O}+2 \mathrm{e}^{-} & \text {electrochemical oxidation of hydrogen } & \text { (reaction III) } \\ \mathrm{CO}+\mathrm{O}^{2-} \rightarrow \mathrm{CO}_{2}+2 \mathrm{e}^{-} & \text {electrochemical oxidation of carbon monoxide (reaction IV) }\end{array}$

$\mathrm{O}_{2}+4 \mathrm{e}^{-} \rightarrow 2 \mathrm{O}^{2-}$

electrochemical reduction of oxygen

(reaction $\mathrm{V})$

Concerning the combustions of methane, only partial combustion (reaction II) is suitable for SCSOFC efficiency by producing hydrogen contrary to total combustion (reaction I). However, other reactions can lead to hydrogen production such as water gas shift (reaction VI) and reforming reactions (reactions VII, VIII and IX). 
$\mathrm{CO}+\mathrm{H}_{2} \mathrm{O} \rightarrow \mathrm{CO}_{2}+\mathrm{H}_{2}$

water gas shift

(reaction VI)

$\mathrm{CH}_{4} \rightarrow \mathrm{C}+2 \mathrm{H}_{2}$

methane cracking

steam reforming

dry reforming (reaction VII)

(reaction VIII)

(reaction IX)

For intermediate temperatures range $\left(500-700^{\circ} \mathrm{C}\right)$, doped ceria with samarium (SDC) or gadolinium (CGO) seems to be the most promising electrolyte with an ionic conductivity of $0.025 \mathrm{~S} \mathrm{~cm}^{-1}$ for $\mathrm{Ce}_{0.9} \mathrm{Gd}_{0.1} \mathrm{O}_{1.95}$ composition at $600^{\circ} \mathrm{C}$ [5].

The frequently used material for the anode is a cermet made of nickel and electrolyte material. Indeed, the nickel is a good catalyst for the partial combustion of methane (reaction II).

The cathode material of a SC-SOFC should not catalyze any combustion of methane and must be stable under a partially reducing atmosphere. Our previous study has shown that $\mathrm{La}_{0.6} \mathrm{Sr}_{0.4} \mathrm{Co}_{0.2} \mathrm{Fe}_{0.8} \mathrm{O}_{3-\delta}$ (LSCF) offers a good compromise between stability and low catalytic activity toward oxidation of hydrocarbons [6].

Concerning the various geometries of SC-SOFC, the most promising geometry is anodesupported cells. At this time, the best performances are obtained for anode-supported cell with a maximum power density of $1500 \mathrm{~mW} \mathrm{~cm}^{-2}$ [7]. To obtain this performance, Shao et al. worked

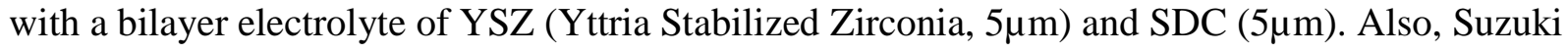
et al. [8] obtained a performance of $660 \mathrm{~mW} \mathrm{~cm}^{-2}$ with an electrolyte made by screen-printing with YSZ. Even if a porous electrolyte is allowed in case of SC-SOFC since it has no more tightening role, they reported that the open circuit voltage $(\mathrm{OCV})$ is lower than in the case of a dense electrolyte. 
Furthermore, an important working parameter for SC-SOFC is methane-to-oxygen ratio (Rmix); the value of Rmix which brings the best power density is not clearly defined in literature. Thermodynamically, Rmix has to be between 0.5 and 2, which corresponds to the stoichiometric ratio of the total (reaction I) and the partial (reaction II) combustions of methane respectively [3]. According to the modeling of Hao and Goodwin, the best power density is obtained for Rmix equal to 1.67 [9]. But experimentally, an increase of power density is observed when Rmix increases to 2 for some authors [10-11], or when Rmix decreases to 1 for other authors [12-13]. These various behaviors are mainly due to the differences of the geometrical configuration. Another major challenge for SC-SOFC is the optimization of their efficiency and particularly the fuel utilization. At present, the highest value of fuel utilization reported is $11 \%$ [13] which is strongly dependent on running parameters (gas flow rate, Rmix, temperature) and bench test geometry.

The first objective of this study is to set an in situ reduction protocol of the anode (NiO-CGO) without carbon deposition and without degradation of the cathode. Since papers report different reduction methods, there is not clear trend for successful anode reduction without degradation of the others cell components (i.e. electrolyte and cathode). Akhtar et al. [13] and Zhang et al. [14] reduced in situ the anode under pure methane, under working atmosphere or under hydrogen. The reduction under $\mathrm{H}_{2}$ was the fastest but cathode degradation could occur. Zhang et al. [14] studied also an ex situ reduction of the anode before cathode processing that leads to the best performances but implies more steps in the preparation process.

The second objective of this work is to optimize the power density and the fuel efficiency of anode supported fuel cells. As the performances of SC-SOFC are influenced by the temperature and Rmix, the performances of a first cell are investigated for a furnace temperature from $600^{\circ} \mathrm{C}$ to $525^{\circ} \mathrm{C}$ each $25^{\circ} \mathrm{C}$ for various $\mathrm{Rmix}(1.5,1,0.8$ and 0.6$)$. The influence of electrolyte 
microstructure is investigated at $600^{\circ} \mathrm{C}$ for each $\mathrm{Rmix}$ with a second cell prepared with a thicker electrolyte.

\section{Experimental}

\subsection{Materials and cells preparation}

For the SC-SOFC preparation, commercial powders are used in this study. CGO, acquired from Fuel Cell Materials, is used for the electrolyte. The cathode is made of LSCF from Fuel Cell Materials and for the anode, $\mathrm{NiO}$ powder from Sigma-Aldrich is used.

The anode powder is a mixture of $\mathrm{NiO}(60 \mathrm{wt} \%)$ and $\mathrm{CGO}(40 \mathrm{wt} \%)$ which have been mixed in a ball mill for 5 minutes in order to homogenize the powders and break agglomerates. This powder is then pressed at $120 \mathrm{MPa}$ and annealed at $1200^{\circ} \mathrm{C}$ during 2 hours to obtained anode pellets. The resulting anode pellets are $20 \mathrm{~mm}$ in diameter and $1 \mathrm{~mm}$ in thickness.

The electrolyte inks are prepared by mixing CGO powder with a binder (ESL V400, $0.5 \mathrm{~g}$ per gram of powder) and a solvent (ESL T404). Two ratios of solvent are used, $0.26 \mathrm{~g}$ per gram of powder for the first ink (ink 1) and $0.15 \mathrm{~g}$ per gram of powder for the second ink (ink 2). Inks are then homogenized and desagglomerated in a rolling mill. Five layers of electrolyte ink are screenprinted on the whole surface of the previous anode with a drying step at $120^{\circ} \mathrm{C}$ for each layer. The cell is firstly annealed at $1200^{\circ} \mathrm{C}$ during 6 hours and at $1400^{\circ} \mathrm{C}$ during 4 hours for the final annealing.

The cathode ink, with $70 \mathrm{wt} \% \mathrm{LSCF}$ and $30 \mathrm{wt} \% \mathrm{CGO}$, is prepared by adding binder $(0.5 \mathrm{~g}$ per gram of powder) and $0.15 \mathrm{~g}$ of solvent per gram of powder. Two cathode layers are then screen- 
printed on the electrolyte with a smaller surface area $(\varnothing 17 \mathrm{~mm})$ than the electrolyte to avoid short circuit between anode and cathode. The cathode is annealed at $1100^{\circ} \mathrm{C}$ during 2 hours and finally, a gold mesh is screen-printed on the cathode with a commercial gold ink (ESL 8880-H) as a current collector.

\subsection{Characterizations}

For all the next experiments, in methane/oxygen/nitrogen mixtures, oxygen is set at $10 \%$ in order to avoid the flammability area of methane.

For the study of anode reduction, thermo-gravimetric analyses (TGA) are performed with a Mettler Toledo device including a differential scanning calorimetry equipment (DSC); the total gas flow is set at $10 \mathrm{~L} \mathrm{~h}^{-1}$ for all gas mixture.

Fuel cell experiments are performed in a quartz tube with a thermocouple placed near the cell. The experimental setup is similar to the one developed by Morel et al. [15]. The cell is pressed between two gold meshes in order to performed 4-wires measurements and the gas mixture is allowed to flow on both sides of the cell through the channels of the sample holder (Fig. 1). A VersaSTAT3 potentiostat-galvanostat is used for OCV and polarization measurements. The gas

flow is set at $30 \mathrm{~L} \mathrm{~h}^{-1}$ for fuel cells tests. The power density is calculated with the cathode surface $\left(2.27 \mathrm{~cm}^{2}\right)$.

Fuel utilization and efficiency of the cells are also calculated [2, 16-17]. Fuel utilization $\left(\eta_{(\mathrm{f})}\right)$ corresponds to current efficiency and is calculated as the current corresponding to the maximum power density ( $\left.\mathrm{I}_{\mathrm{Pmax}}\right)$ divided by the theoretical current obtained if all the fuel is consumed. 
$\eta_{(\mathrm{f})}=\frac{\operatorname{IPmax}}{\mathrm{nF} \frac{\mathrm{dn}\left(\mathrm{CH}_{4}\right)_{\text {initial }}}{\mathrm{dt}}}$

with $\frac{\mathrm{dn}\left(\mathrm{CH}_{4}\right)_{\text {initial }}}{\mathrm{dt}}$ : the initial molar flow of methane, F: the Faraday constant and n: the number of electrons involved in the reaction. For methane, the number of electrons $n$ really implicated is not clearly defined in literature. The maximum of electrons theoretically produced with the direct electrochemical oxidation of methane is 8 , according to reaction $\mathrm{X}$. This value is chosen for fuel utilization calculation.

$\mathrm{CH}_{4}+4 \mathrm{O}^{2-} \rightarrow 2 \mathrm{H}_{2} \mathrm{O}+\mathrm{CO}_{2}+8 \mathrm{e}^{-}$

The efficiency of a cell includes three elements: the thermodynamic efficiency $\left(\eta_{(\mathrm{th})}\right)$, the voltage efficiency $\left(\eta_{(\mathrm{V})}\right)$ and the fuel utilization $\left(\eta_{(\mathrm{f})}\right)$.

$\eta=\eta_{(\mathrm{th})} \times \eta_{(\mathrm{V})} \times \eta_{(\mathrm{f})} \quad \quad$ (Equation 2)

The thermodynamic efficiency is $\eta_{\text {(th) }}=\frac{\Delta \mathrm{G}^{\circ}(\mathrm{T})}{\Delta \mathrm{H}^{\circ}(\mathrm{T})}$ and is equal to 1 taking into account reaction I. The voltage efficiency, $\eta_{(\mathrm{V})}$, is defined as the ratio of the operating cell voltage under load, $U$, to the open circuit voltage.

Microstructures of cells are characterized by a scanning electron microscope (SEM) Jeol JSM 6400. 


\section{Results and discussion}

\subsection{In situ reduction of the anode}

In order to initiate the SC-SOFC after its preparation, the nickel oxide of the anode has to be reduced in metallic nickel. Hydrogen is used for conventional fuel cells, but for SC-SOFC, as both electrodes are exposed to the same atmosphere, the cathode can be degraded by this reducing gas [4]. A reduction of the anode under working condition does not always succeed [14], and takes very long time when it happens; Akhtar et al. fully reduced the anode after 8 hours under $\mathrm{Rmix}=2$ [13]. They also tested a reduction under pure methane but the anode was damaged by carbon formation.

Hence, in this study, the reduction of the anode is performed under different atmospheres at $700^{\circ} \mathrm{C}$ by thermo-gravimetric analyses (TGA) coupled with differential scanning calorimetry (DSC).

First experiment is carried out under $10 \%$ of methane diluted in nitrogen (Fig. 2). A weight loss is observed during the firsts 13 minutes and is then followed by a weight gain. The initial weight loss is attributed to the reduction of $\mathrm{NiO}$ by methane. A strong decrease of heat flow variation at the beginning of the experiment is observed. This endothermic phenomenon is due to $\mathrm{NiO}$ reduction by $\mathrm{CH}_{4}$ (reactions XI and XII).

$$
\begin{array}{lll}
\mathrm{CH}_{4}+\mathrm{NiO} \rightarrow \mathrm{Ni}+2 \mathrm{H}_{2}+\mathrm{CO} & \Delta \mathrm{H}^{\circ}\left(700^{\circ} \mathrm{C}\right)=213 \mathrm{~kJ} \mathrm{~mol}^{-1} & \text { (reaction XI) } \\
\mathrm{CH}_{4}+4 \mathrm{NiO} \rightarrow 4 \mathrm{Ni}+2 \mathrm{H}_{2} \mathrm{O}+\mathrm{CO}_{2} & \Delta \mathrm{H}^{\circ}\left(700^{\circ} \mathrm{C}\right)=139 \mathrm{~kJ} \mathrm{~mol}^{-1} & \text { (reaction XII) }
\end{array}
$$


Then, heat flow variation increases but stays negative. That can be explained by a decreases of reduction reactions and/or also by the start of another endothermic reaction: methane cracking (reaction VII) with an enthalpy change of $\Delta \mathrm{H}^{\circ}\left(700^{\circ} \mathrm{C}\right)=89 \mathrm{~kJ} \mathrm{~mol}^{-1}$. Furthermore, the weight never decreases enough to consider complete reduction of nickel oxide $(12.85 \%$, dashed red line in Fig. 2) and even increases from 13 minutes to the end of the experiment. That suggests there is carbon deposition from methane cracking. After the experiment, the sample has a black color; typical of carbon.

This first experiment confirms carbon deposition during the reduction of nickel oxide under methane as reported elsewhere [13-14]. It is also important to notice that, at the very beginning of the experiment, there are mainly reactions of reduction (reactions XI and XII).

Consequently, in the second experiment of anode reduction, methane is flowed only during the firsts 3 minutes and then an atmosphere with $\mathrm{Rmix}=2\left(\mathrm{CH}_{4}-\mathrm{O}_{2}-\mathrm{N}_{2}: 20-10-70\right)$ is flowed before methane cracking reaction occurs with carbon deposition. Weight variation and heat flow of this new anode reduction experiment are reported in Fig. 3. During the first 3 minutes, there is a weight loss and the heat flow is endothermic, nearly the same as the previous experiment. That means that reactions of nickel oxide reduction by methane are occurring (reactions XI and XII). After 3 minutes under methane, the gas mixture $\mathrm{Rmix}=2$ is injected and this brings about a strong increase of heat flow variation that becomes positive. Exothermic reactions of methane combustions occur (reaction I, $\Delta \mathrm{H}^{\circ}\left(700^{\circ} \mathrm{C}\right)=-400 \mathrm{~kJ} \mathrm{~mol}^{-1}$ and reaction II, $\Delta \mathrm{H}^{\circ}\left(700^{\circ} \mathrm{C}\right)=-45$ $\mathrm{kJ} \mathrm{mol}^{-1}$ ). Concerning the weight variation, there is a gradual loss until it has reached the theoretical value of the reduced anode weight. After 15 minutes, the weight is stable and the anode fully reduced. The experiment is carried out during 4 more hours under Rmix $=2$ and there 
is no more variation in weight and heat flow. After the experiment, the sample is grey as metallic nickel is. This reduction procedure allows to have a fast and complete reduction of the anode without carbon deposition.

\subsection{Characterization of fuel cells}

Before each cell measurement, the previous anode reduction procedure is applied. It is checked that this treatment does not induce cathode degradation. The electrolyte of the first cell is prepared with ink 1 (as defined in experimental part 2.1) so the corresponding cell is named cell 1. The second, prepared with ink 2 is named cell 2.

\subsubsection{Cell 1}

The micrograph of the cell 1 is reported in Fig. 4. Electrolyte is porous and is about $25 \mu \mathrm{m}$ thick. Interfaces between anode and electrolyte and between electrolyte and cathode are well defined. LSFC-CGO cathode is $20 \mu \mathrm{m}$ thick.

Characterization of cell 1 is performed at a furnace temperature from $600^{\circ} \mathrm{C}$ to $525^{\circ} \mathrm{C}$ each $25^{\circ} \mathrm{C}$. Tests are not performed below $525^{\circ} \mathrm{C}$ because of the loss of the OCV due to the lack of catalytic activity of the cermet anode towards methane oxidation at lower temperature [2]. For each temperature step, polarization measurements are done for $\mathrm{Rmix}=1.5,1,0.8$ and 0.6. An exothermic effect is observed due to combustion reactions (reactions I and II) so the sample temperature is higher than the furnace temperature. The temperature difference between sample and furnace $(\Delta \mathrm{T})$ for both cells is between $45^{\circ} \mathrm{C}$ and $55^{\circ} \mathrm{C}$ in the temperature range studied (Fig. 
5). This exothermic effect depends on temperature and Rmix. $\Delta \mathrm{T}$ slightly increases with the temperature, but its main variation is with Rmix: $\Delta \mathrm{T}$ increases when $\mathrm{Rmix}$ decreases.

Indeed, the total combustion (reaction I) is more exothermic $\left(\Delta \mathrm{H}^{\circ}\left(700^{\circ} \mathrm{C}\right)=-400 \mathrm{~kJ} \mathrm{~mol}^{-1}\right)$ than partial combustion (reaction II) $\left(\Delta \mathrm{H}^{\circ}\left(700^{\circ} \mathrm{C}\right)=-45 \mathrm{~kJ} \mathrm{~mol}^{-1}\right)$, corresponding to $\mathrm{Rmix}=0.5$ and to Rmix $=2$ respectively. This may explain the higher exothermic effect when Rmix decreases as it has already been mentioned by Morel et al. [15]. For next tests, the temperature mentioned for fuel cell test is the furnace temperature.

At $600^{\circ} \mathrm{C}$, performances of cell 1 operating in different Rmix are presented in Fig. 6. Concerning OCV, it is lower than SC-SOFC with a dense electrolyte [8] which reaches generally $0.8-0.9 \mathrm{~V}$. Here, the highest $\mathrm{OCV}$, around $0.48 \mathrm{~V}$, is obtained for $\mathrm{R}_{\mathrm{mix}}=0.6$. An increase of $\mathrm{OCV}$ is noticed when $R_{\text {mix }}$ decreases, particularly from $R_{\text {mix }}=0.8$ to $R_{\text {mix }}=0.6$. Performances follow the same trend as the OCV and the maximum power density obtained is $60 \mathrm{~mW} \mathrm{~cm}{ }^{-2}$ for $\mathrm{Rmix}=0.6$ at this temperature.

Better performances are obtained by decreasing the temperatures. OCV (Fig. 7) and maximum power densities (Fig. 8) are reported as function of the temperature for the different Rmix. It's noteworthy that OCV values and power densities follow the same variation and increase when the temperature decreases. The influence of Rmix is the same as previously mentioned, and mostly when decreasing to $\mathrm{Rmix}=0.6$. The highest $\mathrm{OCV}$ value of $0.7 \mathrm{~V}$ and the maximum power density, about $110 \mathrm{~mW} \mathrm{~cm}{ }^{-2}$, are obtained at $525^{\circ} \mathrm{C}$ under $\mathrm{Rmix}=0.6$. 
Fuel utilization and efficiency of the cell are then calculated for cell 1 (Fig. 9) according to equations 1 and 2, respectively. They follow the same trend as power density regarding influence of temperature and Rmix. However, as fuel utilization and efficiency calculations take into account performances and initial fuel flow (equation 1), and as here best performances are obtained when fuel flow is minimal $(\operatorname{Rmix}=0.6)$, influence of $\mathrm{Rmix}$ is more significant for fuel utilization and efficiency (Fig. 9) than for power densities (Fig. 8). The highest fuel utilization and efficiency are obtained for $\mathrm{Rmix}=0.6$ at $525^{\circ} \mathrm{C}$ and are of $3.7 \%$ and $2.3 \%$ respectively. These values are in agreement with other results of SC-SOFC $[8,18]$.

\subsubsection{Cell 2}

Cell 2 presents a thicker electrolyte of $50 \mu \mathrm{m}$ (Fig. 10) compared to cell 1 . This is in accordance with inks preparation. Indeed, ink 2 contains less solvent than ink 1 and so leads to thicker layers. The fracture between anode and electrolyte that can be seen onto the micrograph of tested cell is due to an electrical problem (strong over-potential applied) with the measurement equipment that occurred after the experiment. Cell 2 could only be characterized at $600^{\circ} \mathrm{C}$. The results obtained for cell 2 at different Rmix are presented in Fig. 11. The OCV and the maximum power density increase when Rmix decreases, like for cell 1 . At $\mathrm{Rmix}=0.6,160 \mathrm{~mW} \mathrm{~cm}^{-2}$ are reached. In these experimental conditions, fuel utilization and efficiency of cell 2 are of $6 \%$ and $3.4 \%$ respectively.

\section{$\underline{\text { 3.2.3. Discussion and comparison of cells performances }}$}

The best performances for the 2 cells are obtained at very low Rmix compared to the results published in the literature where Rmix is commonly between 1 and 2 [7, 9-13]. Results reported 
are obtained with dense electrolyte; in this study electrolytes are porous. According to Suzuki et al. [8], for a porous electrolyte, diffusion of hydrogen from the anode to the cathode through the electrolyte pores can occur lowering the oxygen partial pressure at the cathode side and thus decreasing the OCV. At Rmix $=0.6$, less methane is flowed so less hydrogen is produced compared to higher Rmix. This can explained that OCV increases when Rmix is low because of less hydrogen diffusion.

Comparing the two cells, for the same temperature of $600^{\circ} \mathrm{C}$ and $\mathrm{Rmix}=0.6, \mathrm{OCV}$ increases from $0.48 \mathrm{~V}$ to $0.67 \mathrm{~V}$, maximum power density from $60 \mathrm{~mW} \mathrm{~cm}^{-2}$ to $160 \mathrm{~mW} \mathrm{~cm}^{-2}$ and fuel utilization from $3 \%$ to $6 \%$ respectively for cells 1 and 2 . The difference between these cells lies on thicknesses of the electrolytes, given that both are porous. Cell 2, which presents the best performances, has a thicker electrolyte. This is not the expected trend for conventional cells in regard of ohmic drop in electrolyte. It seems that the higher the thickness of electrolyte is, the lower the diffusion of hydrogen is. This is in agreement with the OCV value of cells. So the ohmic drop due to electrolyte thickness is compensated here by hydrogen diffusion limitation.

\section{Conclusion}

Anode supported single chamber SOFC are investigated regarding the in situ reduction of the anode and the cells behavior versus temperature and Rmix for different electrolyte microstructures.

First, a study of anode reduction by thermogravimetric analyses leads to a fast and efficient route of in situ reduction of the anode. Indeed, a successful reduction of the anode without carbon 
deposition is obtained at $700^{\circ} \mathrm{C}$ after a treatment of 3 minutes in diluted methane atmosphere followed by $\mathrm{Rmix}=2$ atmosphere during 12 minutes.

Then characterizations of cells in single chamber atmosphere are performed. Influences of temperature and Rmix atmosphere are evaluated. OCV and maximum power density increase when temperature and Rmix decrease. This is related to the porous microstructure of the electrolyte. In this case, the diffusion of hydrogen from the anode side to the cathode side is possible through the pores of the electrolyte. At low methane gas flow (low Rmix) and at low temperature, this diffusion is limited and thus OCV is increased. The cell with a thicker electrolyte follows the same behavior versus Rmix but the OCV is greatly higher. This OCV improvement seems due to higher thickness of electrolyte which slows down the diffusion of hydrogen between the two electrodes. Furthermore, this second cell showed a maximum power density of $160 \mathrm{~mW} \mathrm{~cm}^{-2}$ at $600^{\circ} \mathrm{C}$ for $\mathrm{Rmix}=0.6$ with a fuel utilization of $6 \%$. Fuel utilization is even more improved because the maximum power density is obtained at the lowest fuel flow. For both experimented cells, OCV seems to be the predominant parameter to enhance the cell performances. A better densification of the electrolyte should improve the OCV and then the maximum power density.

\section{Acknowledgments}

The authors thank ADEME (French Environment and Energy Management Agency) for financial support of this study in the frame of "MONOPAC500" project. 


\section{References}

[1] M. Yano, A. Tomita, M. Sano, T. Hibino, Solid State Ion. 177 (2007) 3351-3359.

[2] M. Kuhn, T. W. Napporn, Energies 3 (2010) 57-134.

[3] B. Buergler, A. Grundy, L. Gauckler, J. Electrochem. Soc. 153 (2006) A1378-A1385.

[4] J.-P. Viricelle, S. Udroiu, G. Gadacz, M. Pijolat, C. Pijolat, Fuel Cells 10 (2010) 683692.

[5] B. Steele, Solid State Ion. 129 (2000) 95-110.

[6] D. Rembelski, J. P. Viricelle, L. Combemale, M. Rieu, Fuel Cells 12 (2012) 256-264.

[7] Z. Shao, C. Zhang, W. Wang, C. Su, W. Zhou, Z. Zhu, H. J. Park, C. Kwak, Angew. Chem. Int. Ed. 50 (2011) 1792-1797.

[8] T. Suzuki, P. Jasinski, V. Petrovsky, H. Anderson, F. Dogan, J. Electrochem. Soc. 152 (2005) A527-A531.

[9] Y. Hao, D. G. Goodwin, J. Electrochem. Soc. 154 (2007) B207-B217.

[10] X. Jacques-Bédard, T. W. Napporn, R. Roberge, M. Meunier, J. Power Sources 153 (2006) 108-113.

[11] X. Zhu, Z. Lue, B. Wei, Y. Zhang, X. Huang, W. Su, Int. J. Hydrog. Energy 35 (2010) 6897-6904.

[12] T. Hibino, A. Hashimoto, M. Yano, M. Suzuki, S. Yoshida, M. Sano, J. Electrochem. Soc. 149 (2002) A133-A136.

[13] N. Akhtar, S. P. Decent, D. Loghin, K. Kendall, J. Power Sources 193 (2009) 39-48.

[14] C. Zhang, Y. Zheng, R. Ran, Z. Shao, W. Jin, N. Xu, J. Ahn, J. Power Sources 179 (2008) 640-648. 
[15] B. Morel, R. Roberge, S. Savoie, T. W. Napporn, M. Meunier, J. Power Sources 186 (2009) 89-95.

[16] N.Q. Minh, T. Takahashi, Science and Technology of Ceramic Fuel Cells, Elsevier Science Ltd., New York, 1995, pp 15-40.

[17] EG\&G Technical Services Inc., Fuel Cell Handbook, seventh ed., U.S. Department of Energy, West Virginia, 2004.

[18] T. Suzuki, P. Jasinski, V. Petrovsky, H. Anderson, F. Dogan, J. Electrochem. Soc. 151 (2004) A1473-A1476. 


\section{Figure captions}

Fig. 1: Diagram and pictures of the sample holder of the experimental setup for electrical measurements

Fig. 2: Weight variation (TGA) and heat flow (DSC) of the anode under $10 \%$ of $\mathrm{CH}_{4}$ in nitrogen at $700^{\circ} \mathrm{C}$ (dashed line corresponds to the theoretical weight loss of the anode if the reduction of $\mathrm{NiO}$ is total: $12.85 \%)$

Fig. 3: Weight variation (TGA) and heat flow (DSC) of the anode under $10 \%$ of $\mathrm{CH}_{4}$ in nitrogen during 3 minutes and then under $\mathrm{Rmix}=2$ at $700^{\circ} \mathrm{C}$ (dashed line is the theoretical weight $\%$ of the anode if the reduction of $\mathrm{NiO}$ is complete)

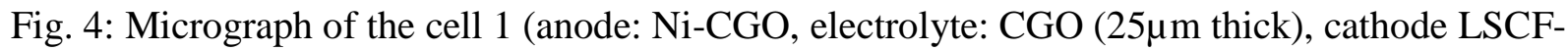
CGO)

Fig. 5: Exothermic effect $(\Delta \mathrm{T}=$ Tsample - Tfurnace) during cell 1 measurement for each Rmix

Fig. 6: Polarization curves of cell 1 at $600^{\circ} \mathrm{C}$ for each Rmix

Fig. 7: OCV of cell 1 versus temperature for each Rmix

Fig. 8: Maximum power densities of cell 1 versus temperature for each Rmix 
Fig. 9: Fuel utilization (left) and efficiency (right) of cell 1 versus temperature for each Rmix


LSCF-CGO)

Fig. 11: Polarization curves of cell 2 at $600^{\circ} \mathrm{C}$ for each Rmix 

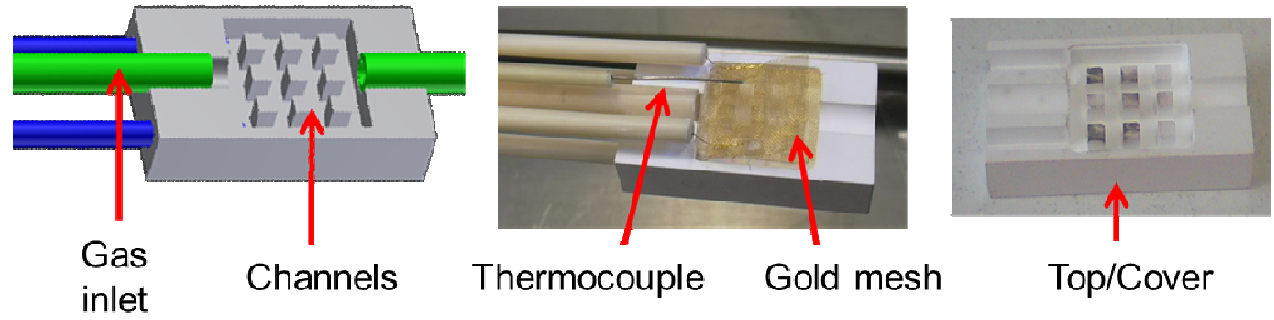

Fig. 1: Diagram and pictures of the sample holder of the experimental setup for electrical measurements

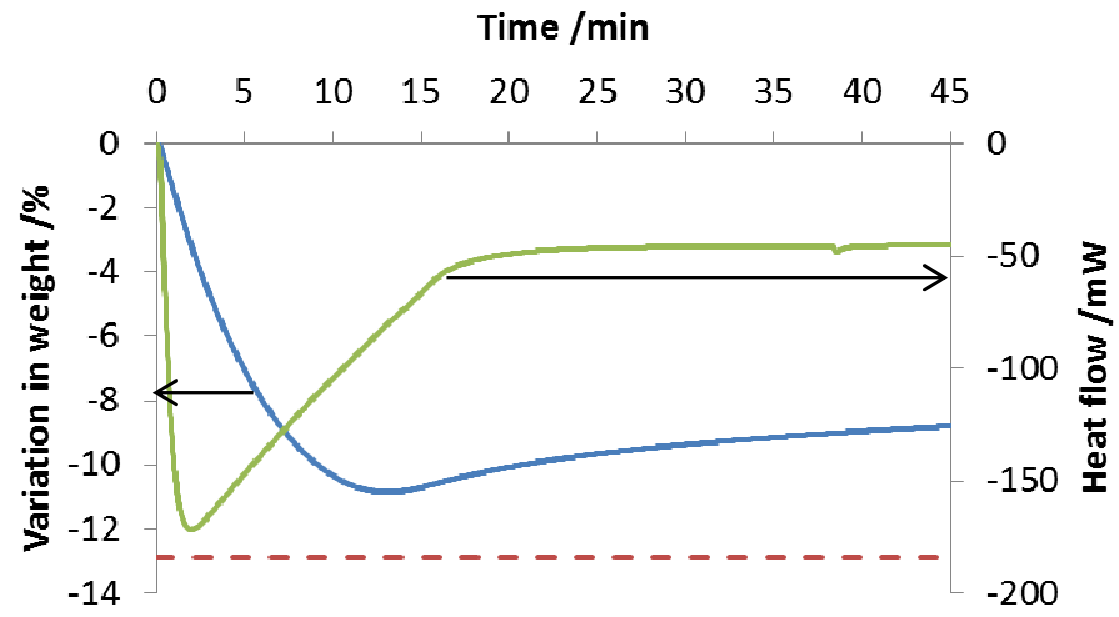

Fig. 2: Weight variation (TGA) and heat flow (DSC) of the anode under 10\% of CH4 in nitrogen at $700^{\circ} \mathrm{C}$ (dashed line corresponds to the theoretical weight loss of the anode if the reduction of $\mathrm{NiO}$ is total: $12.85 \%$ ) 




Fig. 3: Weight variation (TGA) and heat flow (DSC) of the anode under 10\% of $\mathrm{CH} 4$ in nitrogen during 3 minutes and then under $\mathrm{Rmix}=2$ at $700^{\circ} \mathrm{C}$ (dashed line is the theoretical weight $\%$ of the anode if the reduction of $\mathrm{NiO}$ is complete)

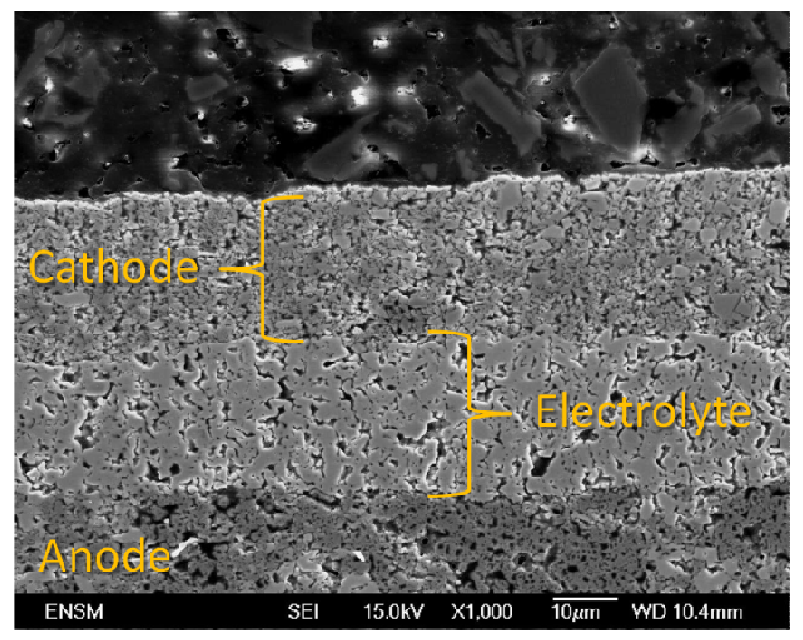

Fig. 4: Micrograph of the cell 1 (anode: Ni-CGO, electrolyte: CGO $(25 \mu \mathrm{m}$ thick), cathode LSCFCGO) 




Fig. 5: Exothermic effect ( $\Delta \mathrm{T}=$ Tsample - Tfurnace) during cell 1 measurement for each Rmix

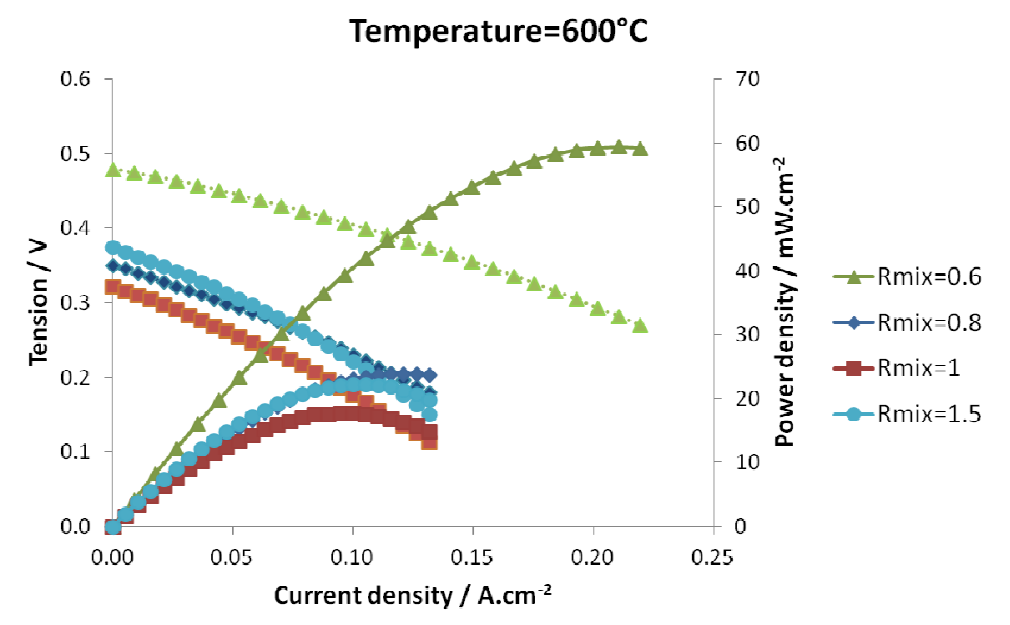

Fig. 6: Polarization curves of cell 1 at $600^{\circ} \mathrm{C}$ for each Rmix 


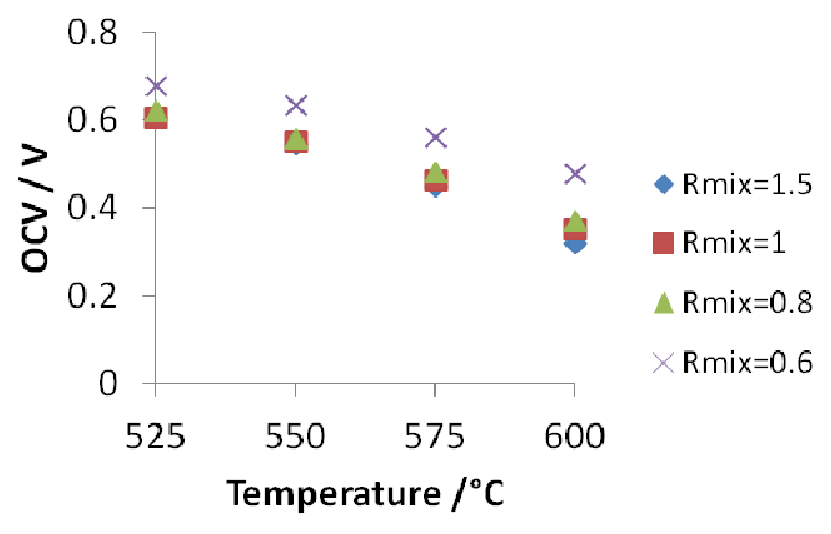

Fig. 7: OCV of cell 1 versus temperature for each Rmix

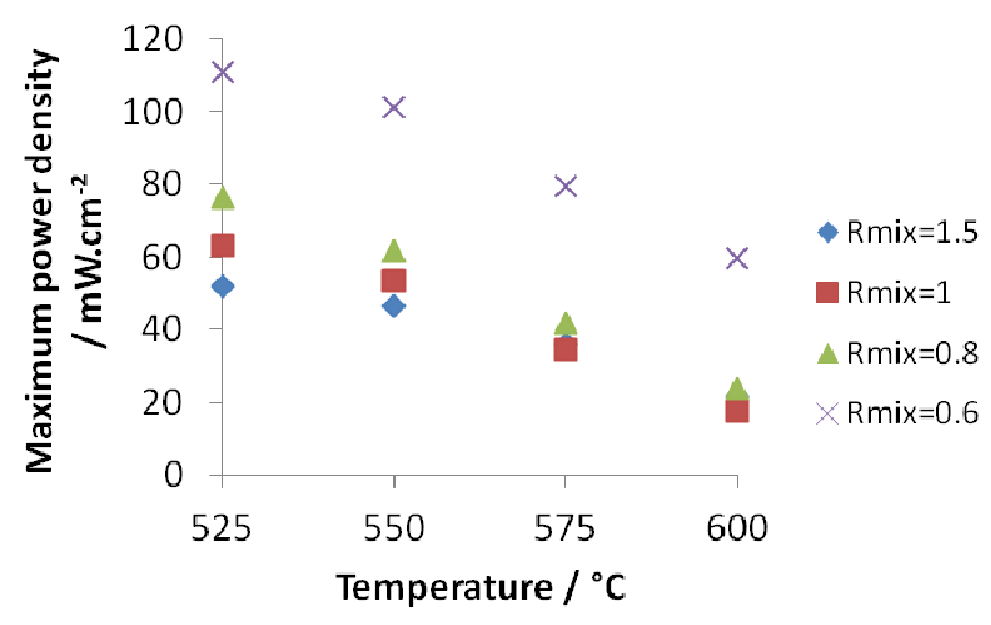

Fig. 8: Maximum power densities of cell 1 versus temperature for each Rmix 

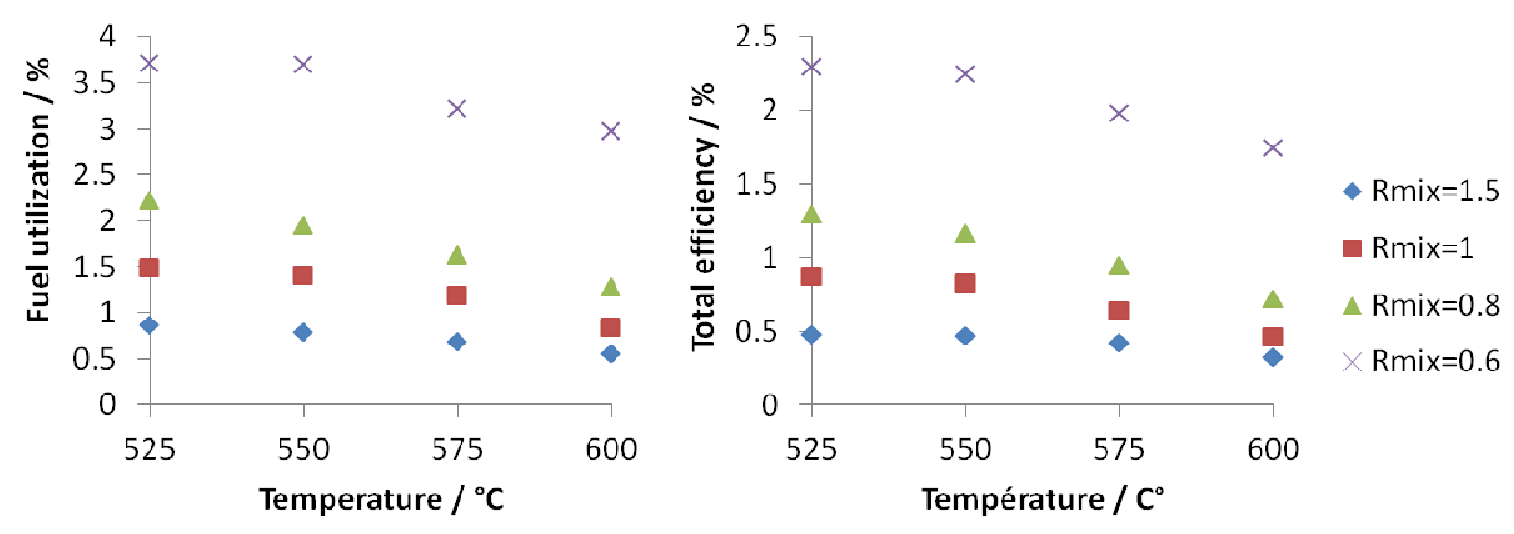

Fig. 9: Fuel utilization (left) and efficiency (right) of cell 1 versus temperature for each Rmix

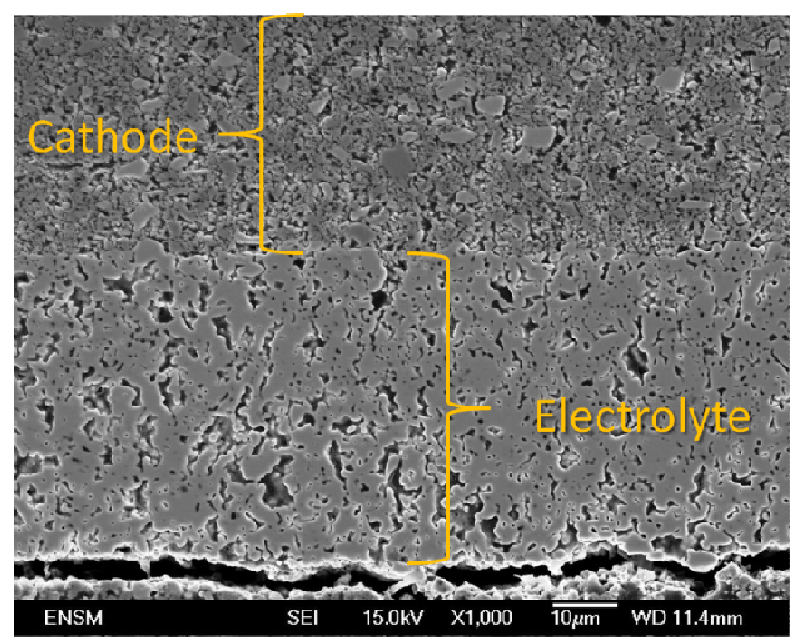

Fig. 10: Micrograph of the cell 2 (anode: Ni-CGO, electrolyte: CGO $(50 \mu \mathrm{m}$ thick), cathode LSCF-CGO) 




Fig. 11: Polarization curves of cell 2 at $600^{\circ} \mathrm{C}$ for each Rmix 